\title{
Putting Babies First: Supportive Choices for Mother and Baby Units
}

Babies have been living in prisons for centuries and yet there is a dearth of literature which examines their conditions. The first known baby in prison was Henry Kable Junior (born in Norwich Castle Gaol (England) in February 1786), he lived with his mother in Norwich Castle Gaol until he and his parents were all transported to Australia. In 'The Pendulum is Stuck - Invisible Agonists and Babies in Prison (Crewe,2020)" I show that the status quo remains because struggles are private, localised, and invisible. Despite attention from politicians, activists, and international human rights; babies continue to live in mother and baby units.

Internationally there is no known accurate data of the number of babies born in prison or the number of dependent infants with their mothers. The age limit of children is different throughout the world and this evidence can illustrate the lack of consistency with the treatment of this minority population. Infants up to the age of 6 years of age can legitimately live with their mothers in Germany and in India children are in prisons until this age without any pre-school education (Crewe, 2020). The only country that does not accommodate new-borns, babies or children in prison is Norway (Crewe, 2020).

The international level of governance has specific rules that relate to conditions in prison, including mother and baby units. The United Nations Rules for the Treatment of Women Prisoners and Non-custodial Measures for Women Offenders (Bangkok Rules) were internationally adopted in 2010 (United Nations General Assembly, 2011). The intention was for the Bangkok Rules to accompany the Standard Minimum Rules for Prisoners and other international or regional non-binding treaties to form an international regulatory framework stating the conditions for women detained in custody. In particular, the Bangkok Rules state that for women with dependent children non-custodial sentences are preferred where possible. Tensions exist between narrowly conceptualised legislation and policies that focus on women as offenders (or mothers in prison) and what is meant by supporting 'the best interests of children'.

Literature about the effects on babies living in mother and baby units is scarce. A document called, 'An Unfair Sentence' explains that the physical incarceration of babies can affect their health and well-being (Galloway, Haynes, and Cuthbert, 2014). Empirical studies about the effect of spending part of their childhood in prison exists but is limited to analysing the developmental progress of babies (Birtsch and Rosenkranz, 1988; Catan, 1989; Gimenz-Salinas, 1988). All authors describe conditions within prison as being restrictive in terms of movement, limited materials or toys and no wide-ranging daily activities, spaces, or social experiences (Jimenez and Palacios, 2003). This is a repetitive argument which does not change the continuation of this practice because it is not radical, uncompromising, or challenging to the status quo. The position of prison reformers has been highlighted as part of the problem and often programs for supporting incarcerated mothers and children do not take into account that they are entangled in the states apparatus of control (Craig, 2009). 
The pandemic of 2020 has increased the visibility of this marginal prison population. A paternalist discourse recognises a need to help 'vulnerable' populations and this advocates the release of women and their babies to protect them from the Covid-19 virus. There has been a change from visible political struggles to internal battles within public bureaucracies which compete to socialize, medicalize, or penalize urban marginality (Waquant, 2010). Unlike most prisoners, babies rely on others to represent their interests. The first section of this article provides an overview of the most salient representations of babies in prison during the current year and its Covid-19 pandemic. I will explain how a theory called, 'supportive choices', can be applied by prison administrations, criminal justice institutions and activists. Inevitably a theoretical framework will have problems when translated into practice, however the intention is to provide a starting point for the transformation of policies or practices that have the intended (or unintended) consequence of putting the interests of women before their babies.

\section{Representations of Mother and Baby Units: Theoretical Implications}

In the context of an expanding neo-liberal political climate and invasive policies, it is necessary to 're-think' the concept of babies in prison (Crewe, 2020). It is easy to see that babies lack power to represent themselves. What is interesting is the first step towards opposing exiting forms of power and revealing a secretive discourse of struggle. The conditions-at-present within mother and baby units are not universally understood. These units exist in female prisons around the world. In Germany women and their babies are described as having 'self-contained flats (Crewe, 2020)' where as within other countries, mother and baby units have been described as places where the 'quality of stimulation' is low (Jimenez and Palencros, 2003). To illustrate the current situation, my starting point will outline three dominant representations (in the United Kingdom) of mother and baby units from 2020.

The first example is a recent representation of the mother and baby unit within HMP Bronzefield which is one of two private female prisons situated in England. In 2020, a self-proclaimed 'best-selling' novel provides a useful description. 'The Prison Doctor' by Dr Amanda Brown (2020), explains that the nursery within the mother and baby unit is, 'bright and airy with a wonderful range of colourful toys and games. There are cots for the babies to nap in and the doors open to a courtyard area'. This has been included within a work of fiction, and it is possible that Dr Brown used her imagination as well as vested interests in providing this description. Despite this, there could be an element of truth behind this account and it is important to recognise that 'a given physical or social milieu is a different psychological environment for everyone who operates in it (Toch, 1992)'.

The Ministry of Justice for England and Wales have released a policy document called a 'Review of Operational Policy on Pregnancy, Mother and Baby Units and Maternal Separation (Ministry of Justice, 2020)'. In a paradox to the Covid-19 health crisis this current policy advocates an extension for the period babies can live in prison and the separation of mothers from their babies from 18 months to 2 years. This second representation links to the political framework of neo-liberalism and contains institutional logics. From a sociological perspective, struggles can be 
defined as 'contests' between various sectors who vie to gain ownership of a social problem so they can provide specific forms of authority and expertise (Waquant, 2010). With this observation in mind, it is not surprising that this review of mother and baby units by the Ministry of Justice in England and Wales included a section dedicated to a 'stakeholder consultation' as an 'opportunity to engage with many interested parties ( Ministry of Justice, 2020)'. Within this review the discourse around the role of mother and baby units is confused, provides incoherent advice and is paradoxical in nature. For example, an important point made by the Ministry of Justice review in England and Wales was that admissions to mother and baby units are made in the 'best interests of the child'. The bias of this review means that it is written from the position of the most powerful. Moreover, it is not clear why 'some stakeholders felt a mother and baby unit should be available in all prisons' as opposed to trying to reduce their populations and implementing the Bangkok Rules (2010) which state that custodial sentences for women with young infants should be a last resort (United Nations General Assembly, 2011).

The final representation of mother and baby units in England has been made by a prison reform organization called, 'The Howard League'. This charitable organization supported a mother and her child in a legal case during the 'lock-down' at the beginning of the Covid-19 pandemic. In England and Wales, the neo-liberal paternalistic government announced plans for the early release of prisoners, including women with babies, to protect them from the harmful effects of the Covid19 virus. In May 2020, the Howard League (2020) publicised that it had successfully represented a young mother and her baby in the Court of Appeal for a reduced sentence and temporary release from prison. The subsequent Ministry of Justice review document (from July 2020) for mother and baby units included details about its 'early release scheme'. This temporary reform could be perceived as progress for the liberation of babies; however, the reverse is equally true. In this case, infants are treated like prisoners because when they are in mother and baby units not only are they are exposed to a well-known health risks, but their release must be connected to their mothers' prison sentence. It is particularly striking that reforms led by people who claim to take into account the 'best interests of children' have created a division of power that in turn has led to a double repression for babies in prison. The legal representation by the Howard League illustrates the current politics of babies in prison and without a theoretical framework there is a circular logic that will continue to maintain the status-quo.

\section{Putting Babies First: Supportive Choices}

Central to the work of all professionals, prison administrations and voluntary organisation is the concept of support. It was research from the 1960's that first highlighted how women in prison support each other through informal networks (Ward and Kassebaum, 1965; Giallombardo, 1966). Support can be a complicated concept because what is helpful for one person could be a problem for another. In the context of imprisonment, support has been defined as: to help carry the weight of or bear pressure; to give aid or courage; approval and strength; to ease the strain (Leibling, 2004). There may be different forms of support provided by a range of departments within the prison service such as the mother and baby unit, 
resettlement services, chaplaincy as well as voluntary or community organisations that may be providing support to women. Social support has been associated with the broader context of prison climate and prison officer attitudes (Ross, Liebling, and Tait, 2011).

This theory will use the concept of social support and link two of its dimensions, as advocated by Tombs (2003). The first dimension of support is how networks provide a support structure. Within the prison these networks are complex and have been described as a 'hybridized net of governance (Kendall 2013)' in order to take into account the multi-disciplinary practitioners that can be employed from voluntary and community organisations and internal prison services such as the mother and baby unit. As well as formal networks it is possible that women receive support from small 'not quite' organised groups that remain 'under the radar (Billis 2010)'.

The second dimension is the support process. According to Tombs (2003) the support process consists of the day-to-day interactions between women and others who are supporting them. This dimension of support will recognise how the daily communication and support provided from inter-agency and inter-professional collaboration works in informal ways and is different from formal partnership working.

The problem with being supportive is that this does not always lead to change because within prisons power is always exercised at the expense of people. Early sociological studies of prisons recognised the separation of prisoners from their communities and focused on how prisoners cope with the pains of imprisonment. Sykes (1958) suggested the restriction on choices was one of the 'pains of imprisonment' where prisoners are deprived of autonomy, liberty, security, relationships, goods, and services. In-depth research that has been conducted within male prisons has explained that power is a central concept for understanding imprisonment and security measures have been considered as dynamic and subtle. This softer power means there are new ways prisoners may be victimised and access to services is restricted through abuses of the power of bureaucracy (Crewe, 2009; Crewe, 2011). Moreover, practitioners within complex bureaucracies perceive they are operating under adverse circumstances whereas, in reality, they have a significant degree of discretion (Lipsky, 2010).

Currently the only solution presented is for babies to stay in mother and baby units. Finding supportive choices that can liberate babies from living in mother and baby units will be the first step towards change. Putting babies first, before the prison sentence of women will not only mean thinking about this topic differently, but also changing attitudes. Mechanisms of support are known to be affected by the prison environment, the role of practitioners as well as the attitudes of women in prison. For example, it has been found that female prisoners may be cautious in admitting health problems due the potential for prejudice or stigmatization from staff as well as the requirement to accept treatment (Birmingham, Coulson, Mullee, Kamal and Gregoire, 2006).

The theory of supportive choices will mean initiating a new struggle against existing forms of power. This will not only involve challenging the overall politics that are known to favour neo-liberal political ideals, but also speaking out. There could be 
alternative choices for babies, including having permission to leave their mothers to live in local communities without relying on their mother's prison sentence or live with their mothers on a flexible basis. To try and change institutionalised networks of information, to listen, and find compelling targets is the first step in the reversal of power. Feminist discourse identifies that women need choices to control their own lives may help to produce change. How and to what extent babies will be able to access supportive choices will depend on factors including the work of practitioners.

Within prisons there are practitioners supporting female prisoners from the public, private, voluntary and community sectors. Encouraging supportive choices will be useful for exploring changes and rather than changing legislation a first step would be to recognize that the policy documents and guidance in England and Wales states that the 'best interests of the child' should be taken into account. Multidisciplinary healthcare teams which include midwives or nurses are involved and it is possible that the conditions for babies could be prioritized according to their personal circumstances rather than medical criteria. It is not known whether these options are available for female prisoners' and future research could consider whether it is possible to give babies easier access to families or for a flexible approach to be adopted towards their living arrangements. Within England and Wales, all public sector institutions are in an age of austerity and it will be advantageous to governors of local prisons if this research explores cost savings.

\section{Conclusion}

The process of liberation for babies in prison is not currently understood and it is this challenge to the status quo that has sustained my research. Indeed, Deleuze and Gualtami (1987) state that worthy projects need to 'bring something incomprehensible into the world'. A major hurdle relating to the taken-for-granted understandings of mother and baby units, highlighted in the three representations from this year, concerns their imperceptible nature. According to the philosophy of Deleuze once a problem is captured it is then susceptible to manipulation and loses its ability to produce change (Murphy, 2019). The main justification for creating a theoretical framework is that it will help to explain struggles, define targets of manipulation, and identify the nature of power.

It is easy to see that babies lack the power to have their own voice and it is their lack of representation that has sustained a status quo. The problem persists that babies are living within prisons. Mother and baby units are presented as a solution; however, these living arrangements are not always in the best interests of children. There are no internationally consistent conditions, agreement on the age of separation or discussion about the possible choices for those who are supporting infants living in mother and baby units.

Evidence from the United Kingdom highlights that struggles exist with representing mother and baby units; however, it is the most powerful who lead and define the position of babies. Dominant concerns are linked to the interests of different groups whether these are professionals such as doctors or midwives, government administration or activists. It is difficult to conceive that there could be any other way 
of dealing with women who have young babies and it is this difficulty that has led to the creation and longevity of mother and baby units.

\section{References:}

Billis, D (2010). Hybrid organizations and the Third Sector. Challenges for practice, theory, and policy. Palgrave MacMillan, Hampshire.

Birmingham L, Coulson D, Mullee M, Kamal M and Gregoire A (2006) The mental health of women in prison mother and baby units, The Journal of Forensic Psychiatry and Psychology Vol 17: No 3

Birtsh V and Rosenkranz, J (1988) Mutter und Kinder im Gefangnis Juventa Verlag: Munich

Brown, A (2020) The Prison Doctor: Women Inside London: Harper Collins

Catan L (1989) 'The development of young children in HMP mother and baby units' working paper in Psychology Series No 1: University of Sussex, 1989.

Craig, S (2009) A Historical Review of Mother and Child Programs for Incarcerated Women the Prison Journal 89: 1

Crewe, B (2009) The Prisoner Society, power, adaption and social life in an English prison, Oxford: Oxford University Press.

Crewe B (2011) Soft power in prison: implications for staff-prisoner relationships, liberty and legitimacy European Journal of Criminology, Vol:8 No 6

Crewe, H (2020) Female Prisons Around the World: Facts and Figures about Women in Prison, LAP: Lambert Academic Publishing.

Crewe, H. (2020) When the Pendulum is stuck! - Invisible Agonists and Babies in Prison. Cambridge Open Engage. doi:10.33774/coe-2020-nkn75

Crewe, H (2020) Neo-Liberal Governmentality and Babies in Prison Cambridge Open Engage. https://doi.org/10.33774/coe-2020-6v81b

Deleuze, G and Guattari (1987) A Thousand Pateaus Translated by Brian Massumi, Minneapolis: University of Minnesota Press

Galloway, S, Haynes, A, Cuthbert, C (2014) An unfair sentence, NSPCC, and Barnardo's retrieved 19 November, 2014 from http://www.nspcc.org.uk/preventingabuse/research-andresources/ all-babies-count-unfair-sentence 
Giallombardo, R (1966) Society of women: a study of a women's prison, John Wiley, New York

Gimenez-Salanas, E (1988) Influencia del medi penitenciari sobre el desenvopament psicologic de l'infant. Centre d'Estudis I Formacio Departament de Justica.

Generalitat de Catalunya: Barcelona

Howard League for Penal Reform (2020), Coronavirus: How You Are Helping to Keep People Safe - email 20 May 2020

Jimenez, J and Palacios, $\mathrm{J}$ (2003) When Home is in Jail: Child Development in Spanish Penitentiary Units. Infant and Child Development 12: 461-474

Kendall, K. (2013) Post-release support for women in England and Wales: the big picture in Carlton, B and Segrave, M. (2013). Women exiting prison. Critical essays on gender, post-release support and survival: Routledge, Oxon.

Liebling, A (2004) Prisons and their moral performance: A study of Values, Quality and Prison Life. Oxford: Oxford University Press

Lipsky, M (2010) Street Level Bureaucracy: dilemmas of the individual in public services New York: The Russell Sage Foundation

Ministry of Justice, (2020) "Review of operational policy on pregnancy, Mother and Baby Units and maternal separation: Summary report of the review of PSI 49/2014 and operational policy on pregnancy and women separated from children under 2 in prison". Retrieved on 16 September, 2020 from:

https://assets.publishing.service.gov.uk/government/uploads/system/uploads/attach ment_data/file/905559/summary-report-of-review-of-policy-on-mbu.pdf

Murphy, J (2019) Based Deleuze: The Reactionary Leftism of Gilles Deleuze - selfpublished

Ross M, Liebling A and Tait S (2011) The relationships of prison climate to health service in correctional environments: Inmate health care measurement, satisfaction and access in prisons, The Howard Journal of Criminal Justice, Vol 50: No3

Sykes G (1958) The society of captives: a study of a maximum-security prison, Princeton Paperbacks

Toch, H. (1992) Living in Prison: The Ecology of Survival. New York: The Free Press.

Tombs J (2003) The chance for change: a study of the through-care centre Edinburgh Prison, Occasional Paper Series 4. Edinburgh Scottish Prison Service.

United Nations General Assembly. (2011). Resolution adopted by the General Assembly: 65/229 United Nations Rules for the Treatment of Women Prisoners and Non-custodial Measures for Women Offenders (the Bangkok Rules). Sixty-fifth session: agenda item 105. 
Helen Crewe $-1 / 10 / 20$

Wacquant, L (2010) Crafting the Neoliberal State: Workfare, Prisonfare, and Social Insecurity Sociological Forum Vol 25: 2

Ward D and Kassebaum G (1965) Women's Prison, Sex and Social Structure, Chicago: Aldine Publishing Company 